University of Nebraska - Lincoln

DigitalCommons@University of Nebraska - Lincoln

Publications from USDA-ARS / UNL Faculty

U.S. Department of Agriculture: Agricultural

Research Service, Lincoln, Nebraska

March 2005

\title{
Soil surveys: A window to the subsurface
}

Douglas A. Wysocki

USDA-Natural Resources Conservation Service, Lincoln, NE

P. J. Schoeneberger

USDA-Natural Resources Conservation Service, Lincoln, NE

H. E. LaGarry

University of Nebraska-Lincoln

Follow this and additional works at: https://digitalcommons.unl.edu/usdaarsfacpub

Part of the Agricultural Science Commons

Wysocki, Douglas A.; Schoeneberger, P. J.; and LaGarry, H. E., "Soil surveys: A window to the subsurface" (2005). Publications from USDA-ARS / UNL Faculty. 192.

https://digitalcommons.unl.edu/usdaarsfacpub/192

This Article is brought to you for free and open access by the U.S. Department of Agriculture: Agricultural Research Service, Lincoln, Nebraska at DigitalCommons@University of Nebraska - Lincoln. It has been accepted for inclusion in Publications from USDA-ARS / UNL Faculty by an authorized administrator of DigitalCommons@University of Nebraska - Lincoln. 


\title{
Soil surveys: A window to the subsurface
}

\author{
Douglas A. Wysocki ${ }^{a, *}$, P.J. Schoeneberger ${ }^{\mathrm{a}}$, H.E. LaGarry ${ }^{\mathrm{b}}$ \\ ${ }^{a}$ USDA-Natural Resources Conservation Service, Lincoln, NE 68505-3866, United States \\ ${ }^{\mathrm{b}}$ Conservation and Survey Division, University of Nebraska-Lincoln, Lincoln, NE, United States
}

\begin{abstract}
Soils and underlying parent materials form a continuous system we must understand and manage in total. Numerous concerns (e.g., water quality, on-site waste disposal, landfill placement, and nutrient or pesticide movement) require an integrated knowledge and understanding of soil, the soil-to-substratum transition, and the deeper substratum. Soil C-horizons can exceed the thickness of the overlying A and B-horizons and contain unique morphological properties. The subsolum including C-horizons receives less descriptive emphasis than upper soil horizons. Soil scientists map and classify soils mainly on A and B-horizon properties. Soil forming and hydrologic processes that impart morphological features, however, extend considerably below these horizons. Precise adherence to Soil Taxonomy places an arbitrary constraint on field observations at $2 \mathrm{~m}$. Soil scientists routinely observe $\mathrm{C}$ and $\mathrm{R}$ horizons and deeper underlying substrata in gravel pits, road cuts, barrow pits, foundation excavations, and drill cores, but provide less documentation than for upper horizons. Parent material and stratigraphy need more consideration in soil map unit design and delineation. Field observations by soil scientists below $2 \mathrm{~m}$ are crucial for understanding the subsolum (i.e., the morphology of, and relationships of solum to substratum). Soil surveys can convey concise and more descriptive soil-to-substrata information with little added effort or resources. Soil surveys can accomplish this end by use of block diagrams, parent material maps, and geomorphic maps that include both pedostratigraphic and lithostratigraphic detail. Soil surveys must develop soil and map unit descriptions linked to measured sections and named stratigraphic units, and describe and analyze soils and parent materials to greater depths $(>2 \mathrm{~m})$. We use case examples to demonstrate these concepts. Soil-to-substrata documentation and presentation conveys crucial information to soil survey users. Soil-to-substrata relationships identified and recorded during a soil survey create a knowledge window to the subsurface.
\end{abstract} (C) 2005 Elsevier B.V. All rights reserved.

Keywords: Block diagram; Lithostratigraphy; Parent material; Pedostratigraphy; Soil survey; Substrata

\footnotetext{
* Corresponding author. Tel.: +1 402437 4155; fax: +1 402437 5336.

E-mail address: Doug.Wysocki@nssc.nrcs.usda.gov (D.A. Wysocki).
}

\section{Introduction}

Soils form into an extensive array of surficial geologic deposits including unconsolidated sediments (alluvial, glacial, marine, eolian), saprolite, and bedrock (weathered and unweathered). Soil science commonly designates this as parent material, which is defined as the mineral or organic material in which

0016-7061/\$ - see front matter (C) 2005 Elsevier B.V. All rights reserved. doi:10.1016/j.geoderma.2004.11.012 
the soil formed, including the kinds of rock from which the regolith is derived (Soil Survey Staff, 1993). Soils may grade into geologic deposits, at shallow depth, that are unrelated or different from the parent material for the solum. Any material layer beneath the solum is called the substratum (pl. substrata) (Soil Science Society of America, 1997). Our discussion focuses on C-horizons and material properties beneath the solum. We will use both terms parent material and substrata to describe the subsolum zone.

Soil (surface) age, intensity and duration of pedologic processes, and parent material characteristics largely determine the type and distribution of soil in landscape (Chadwick and Graham, 2000; Wysocki et al., 2000). Parent material composition influences both soil development and distribution much like the genetic code predetermines the potential characteristics of an organism. Physical, chemical, and mineralogical parent material constituents predetermine the potential soil that can develop despite soil-forming process duration and intensity. For example, parent material composed solely or predominantly of quartz sand, such as outwash (Otter and Fiala, 1978) or dune sands (McCoy et al., 2002), do not develop clay-rich soils. Soil patterns across an outwash or dune landscape primarily reflect the original parent material placement. A soil map in this geologic setting accurately depicts both the soil and the surficial material distribution.

Soil survey information can reliably predict parent material nature and distribution based on soil properties, patterns, and their relationship to the underlying materials. The soil-to-subsurface linkage is not always as clear-cut as the surface form and grain size of a sand dune or outwash plain. Field observations made during soil survey activities provide important ground-truth for understanding parent material distribution regardless of the soil-to-substrata complexity. The detailed field observations made during a soil survey when linked to subsurface information (e.g., drill cores and geologic sections) and other earth science inventories can provide a coordinated, comprehensive earth material inventory.

Soil is the dynamic link between the biosphere and lithosphere. Substratum materials that directly underlie the solum are part of, and directly affect the pedosphere (e.g., water movement and its biogeochemistry) (Graham et al., 1994; Graham and Wald, 1999). The soil-tosubstrata transition is generally gradual and may occur across a depth of several meters (van Dijk, 1969; Prescott and Pendlton, 1952). Soil Taxonomy (Soil Survey Staff, 1998; Soil Survey Staff, 1999) emphasizes A and B-horizon characteristics and uses a $2.0 \mathrm{~m}$ depth limit (formerly $1.5 \mathrm{~m}$, Soil Survey Staff, 1975). Soil description, as a result, focuses on morphological properties of A and B-horizons (Schoeneberger et al., 2002). The C-horizon receives less emphasis than upper horizons, but it encompasses all or part of the soil-to-substrata transition (Tandarich et al., 1994). Observation and descriptions of C-horizons (upper substrata) needs greater emphasis by pedologists. Guy Smith, the principal architect of Soil Taxonomy, recognized this need. Smith (1986) queried “... where ...where the regolith is thick and the soil scientist stops at 2 meters and the geologists starts at 40 meters - who's field is the one in between?"

Soil surveys can improve both C-horizon description and the understanding of the soil-to-substrata linkage without new or major inputs or workload increases. Many of the essential observations and activities already occur during the soil survey process. The key is for soil surveys to document observable soilto-substrata relationships and present this information in an easily perceptible format. Various descriptive procedures and terms presently exist for describing subsolum features and morphology (Clayton and Arnold, 1972; Hallberg et al., 1978; Follmer, 1979; Richardson and Lietzke, 1983; Tandarich et al., 1994; Buol, 1994). The regional and geomorphic approach (MLRA - major land resource area), recently adopted by the USA Soil Survey, affords a unique opportunity to improve descriptions and interpretations for deeper soil horizons, parent material, and underlying substrata. Soil surveys are a window to the subsurface in that the observations, descriptions, data, and maps provide a conceptual and spatial understanding of the parent material. We present below some essential elements that can succinctly convey important soil-to-substrata linkages in a soil survey.

\section{Discussion}

\subsection{Soil survey conventions and limitations}

Two soil survey conventions restrict the ability to convey observable substrata properties and morphol- 
ogy. The first is presentation. Soil scientists use three major inputs to understand and map soil distribution These are existing spatial data (e.g., topographic and geologic maps, DEMs), remote imagery (aerial photographs and satellite imagery), and field observations ("ground truthing") (Fig. 1). Soil surveys chiefly convey soil information via plan-view maps, and written pedon and map unit descriptions. A plan-view map shows soil distribution, but does not display soil depth, parent material, or stratigraphic information. Users must glean substrata and stratigraphic information from the written pedon and map unit descriptions. Table 1 provides both a pedon and map unit description for the Boone series, a soil formed over sandstone. Consider data from the C-horizon and below. The descriptions define the substrata (bedrock) as white, weakly cemented sandstone. Important physical characteristics (e.g., grain size, fractures, porosity, weathering degree, stratification, dip, or formation name) are not provided in either the pedon or map unit descriptions. Field soil scientists likely observed the absence or presence of these and other properties. Soil surveys simply do not routinely report subsolum morphology and characteristics.

Another presentation aspect is that soil surveys commonly list pedon and map unit descriptions alphabetically and in separate locations. In soil surveys, neither pedon nor soil map unit descriptions are organized by parent material or landscape sequence. Users must extract and reconstruct soil-to-substrata relationships from the written descriptions and visualize the spatial distribution from the plan view maps. The written and alphabetized descriptions limit the substrata information conveyed by, but intrinsic in soil surveys.

The second limitation is a central focus on classification. Soil Taxonomy sets a 2 m classification depth and emphasizes $\mathrm{A}$ and B-horizons properties. The substrata and C-horizons receive considerable less attention and documentation in the soil survey process. Various studies demonstrate, however, that biologic (Stone and Commerford, 1994) and pedologic (Gra-

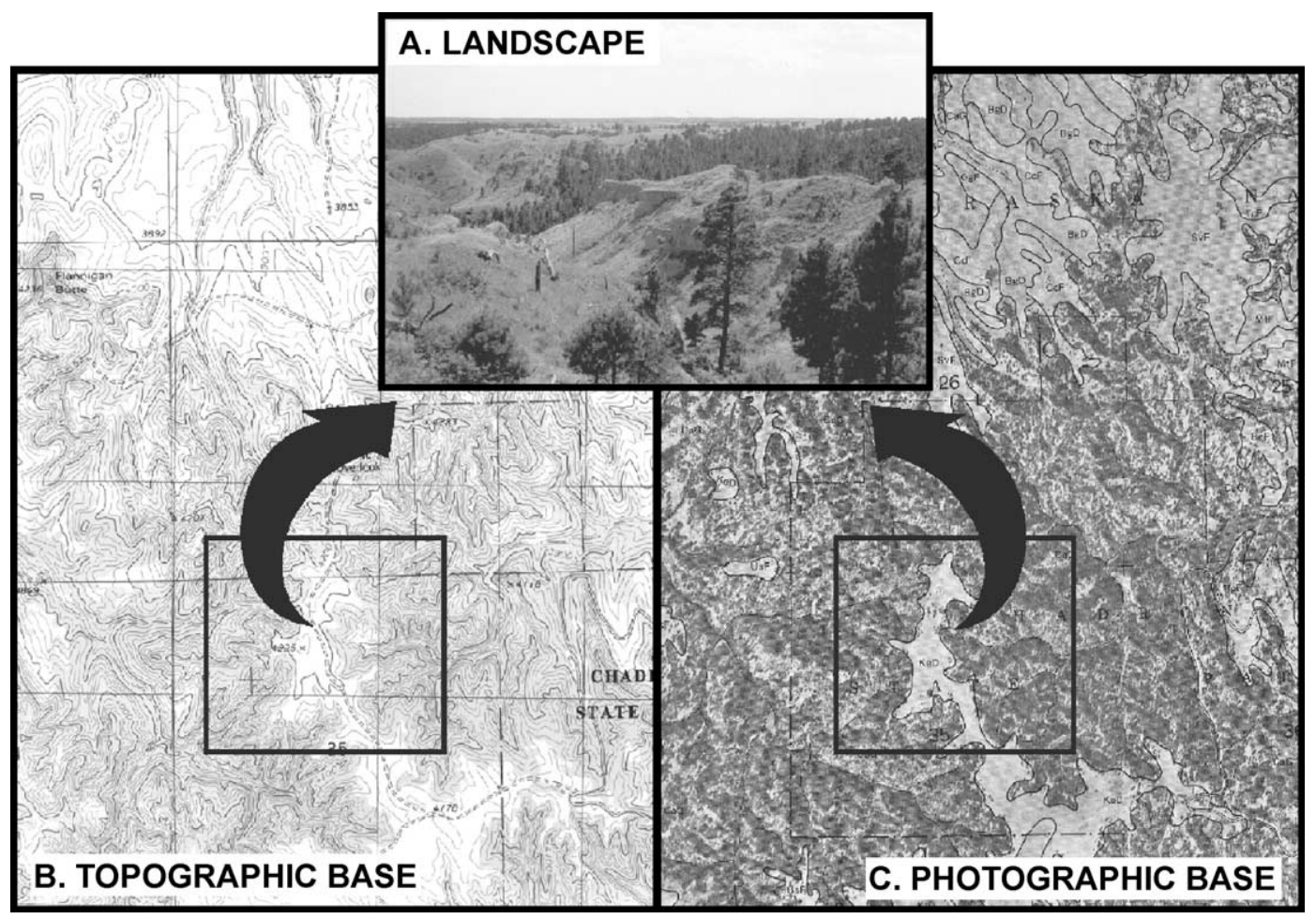

Fig. 1. Soil survey information sources: A. landscape and field observations, B. topographic maps or DEMS, and C. aerial satellite photos. 
Table 1

Pedon and soil map unit descriptions Jackson County Wisconsin Soil Survey (Langton and Simonson, 2001)

\begin{tabular}{|c|c|}
\hline Pedon description Boone Series on $15 \%$ to $50 \%$ slopes & Soil map unit description BoF-Boone sand, $15 \%$ to $50 \%$ slopes \\
\hline $\begin{array}{l}\text { The Boone series consists of excessively drained soils } \\
\text { that are moderately deep to sandstone bedrock on } \\
\text { bedrock-controlled uplands. These soils formed in } \\
\text { siliceous sandy residuum derived from sandstone. } \\
\text { Permeability is rapid on the sandy residuum and } \\
\text { moderately slow or moderate in the underlying } \\
\text { sandstone. } \\
\text { Typical Pedon } \\
\text { Oe-0-3 cm dark grayish brown (10YR 4/2) mucky peat; } \\
\text { weak thin platy structure; non-sticky; very strongly acid; } \\
\text { abrupt smooth boundary. } \\
\text { A-3-8 cm very dark grayish brown (10YR } 3 / 2) \text { sand; } \\
\text { weak fine granular structure; very friable; pale brown } \\
\text { (10YR } 4 / 3 \text { ) uncoated sand grains throughout; strongly acid; } \\
\text { abrupt wavy boundary. } \\
\text { E-8-20 cm brown (10YR } 4 / 3 \text { ) sand; weak medium subangular } \\
\text { blocky structure; very friable, about } 15 \% \text { sandstone channers; } \\
\text { strongly acid; abrupt wavy boundary. } \\
\text { Bw-21-52 cm dark yellowish brown (10YR } 4 / 4) \text { sand weak } \\
\text { coarse subangular blocky structure; very friable; about } 15 \% \\
\text { sandstone channers; strongly acid; clear wavy boundary. } \\
\text { C- } 52-90 \text { cm brownish yellow (10YR } 6 / 6 \text { ) sand; single grain; } \\
\text { loose; about } 10 \% \text { sandstone channers; strongly acid gradual } \\
\text { smooth boundary. } \\
\text { Cr-90-150 cm white (10YR } 8 / 2 \text { ) sandstone. } \\
\text { Solum thickness and sandstone depth range from } 50 \text { to } 100 \mathrm{~cm} \text {. } \\
\text { Sandstone channers averages less than } 15 \% \text { (volume) in the } \\
\text { solum, individual subhorizons may range up to } 35 \% \text { channers. }\end{array}$ & $\begin{array}{l}\text { This moderately deep, moderately steep to very steep, excessively } \\
\text { drained soil occurs on hill shoulders, nose slopes, and back slopes. } \\
\text { Soil delineations are long, narrow and/or irregularly shaped and } \\
\text { range from } 5 \text { to } 120 \text { ha in size. } \\
\text { Typically, the surface layer is dark brown sand about } 8 \mathrm{~cm} \text { thick. } \\
\text { The subsoil is yellowish brown, loose sand about } 40 \mathrm{~cm} \text { thick. } \\
\text { The upper part of the substratum is yellow sand about } 30 \mathrm{~cm} \text { thick. } \\
\text { The lower part to a depth of about } 1.5 \mathrm{~m} \text { is weakly cemented } \\
\text { sandstone. } \\
\text { Included within BoF soil delineations are small areas of very deep, } \\
\text { excessively drained Tarr soils. Tarr soils occur near the lower back } \\
\text { slope to foot slope positions. } \\
\text { Permeability is rapid in the sandy subsoil and substratum and } \\
\text { moderately slow or moderate in the underlying sandstone. } \\
\text { Available water capacity is very low throughout. Organic matter } \\
\text { content is very low or low in the surface layer. The underlying } \\
\text { sandstone limits rooting depth of most plants. }\end{array}$ \\
\hline
\end{tabular}

ham et al., 1994) processes are commonly active in the surface 5 to $10 \mathrm{~m}$ including the soil and upper substrata. Biologic, hydrologic, and chemical processes produce or influence both soil and substrata morphology. This morphology includes horizons, weathering zones, chemical and physical concentrations, and macro void networks (e.g., joints, and cracks) (Pavich et al., 1989; Moody and Graham, 1994; Stolt and Baker, 1994; Tandarich et al., 1994; Frazier and Graham, 2000). The soil and substrata morphology is an essential predictor of vadose zone processes. Surface relief, soils, and the underlying substrata in combination control water flow and contaminant transport in a landscape. Water flow into and through both soils and substrata is a unifying concept and concern. Water flow and constituent transport does not cease at a prescribed depth and has profound environmental implications (Schoeneberger and Amoozegar, 1990; Vepraskas et al., 1991; Schoeneberger et al., 1995; Richardson et al., 2001;
Frazier et al., 2002). Soil descriptions need to be "pedologically complete" and fully explain the soil-tosubstrata morphology in particular those that are water flow indicators.

In practice, soil scientists routinely observe soils, substrata, and stratigraphic relationships below $2 \mathrm{~m}$ (e.g., drill cores, road cuts, stream banks, quarries, barrow pits, construction excavations, sample pits). Soil survey processes and products need to capture and incorporate this field knowledge. Fortunately, recent regional and geomorphic focus (major land resource areas) by the USA Soil Survey lends itself to protocols that better define the soil and substrata relationships.

\subsection{Constructive approaches}

Soil surveys can make subsurface information more explicit and accessible using simple approaches and slight convention modifications. The following prac- 
tices can enhance the utility of subsurface information, and attract a wider audience for soil survey products. 1) Present soil information in published soil surveys organized by substrata and parent material, in addition to existing formats. 2) Document and retain subsurface information, which currently is lost during the soil survey process. 3) Include complimentary subsurface information to augment traditional soil survey data. We suggest use of the following approaches or concepts to capture and convey information on substrata and deeper soil horizons in soil surveys.
1) Block diagrams
2) Lithostratigraphy
3) Pedostratigraphy
4) Parent material maps and tables
5) Geomorphic maps
6) Measured sections

\subsection{Block diagrams}

Soil surveys graphically display soil landscape patterns and generalized substrata information via block diagrams (Fig. 2). Block diagrams are stylized, pictorial representations of soil landscape relationships, which commonly include some substrata representation. Block diagrams, however, rarely include spatially precise depths or stratigraphic relationships. Stratigraphic relationships must be accurately depicted and consistent with field observations. It is easy to omit or misrepresent

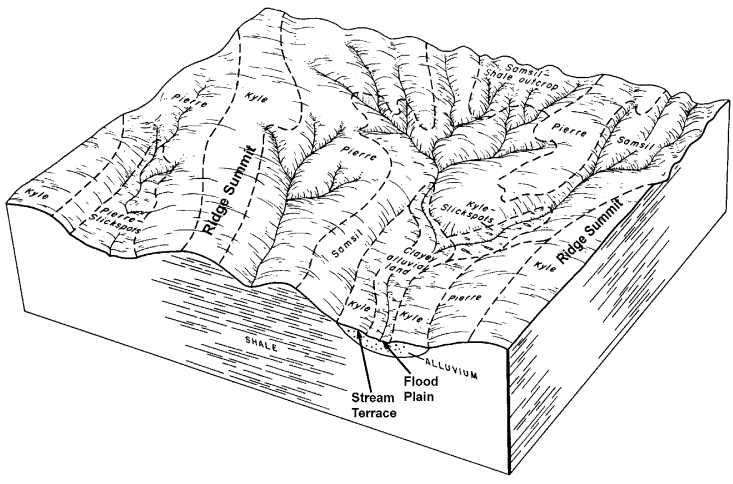

Fig. 3. A block diagram portraying stylized relationships of soil map units to topography and subsurface materials in Dawes County, NE, USA (Ragon et al., 1977).

important stratigraphic detail in a block diagram. Fig. 3 is an example. The alluvium in the right center includes two soil map units-Kyle (parent material Qa2) and "clayey alluvial land" (parent material Qa1). The diagram displays no subsurface relationships between the two alluviums. The Kyle soil and the clayey alluvial land occur on geomorphic surfaces and deposits of different age; an inset relationship exists. An important stratigraphic boundary exists in the subsurface between the clayey alluvium and the Kyle unit. Addition of a single line could depict this relationship on the diagram. Soil scientists likely understood the field stratigraphic relationships, but the block diagram does not display them.

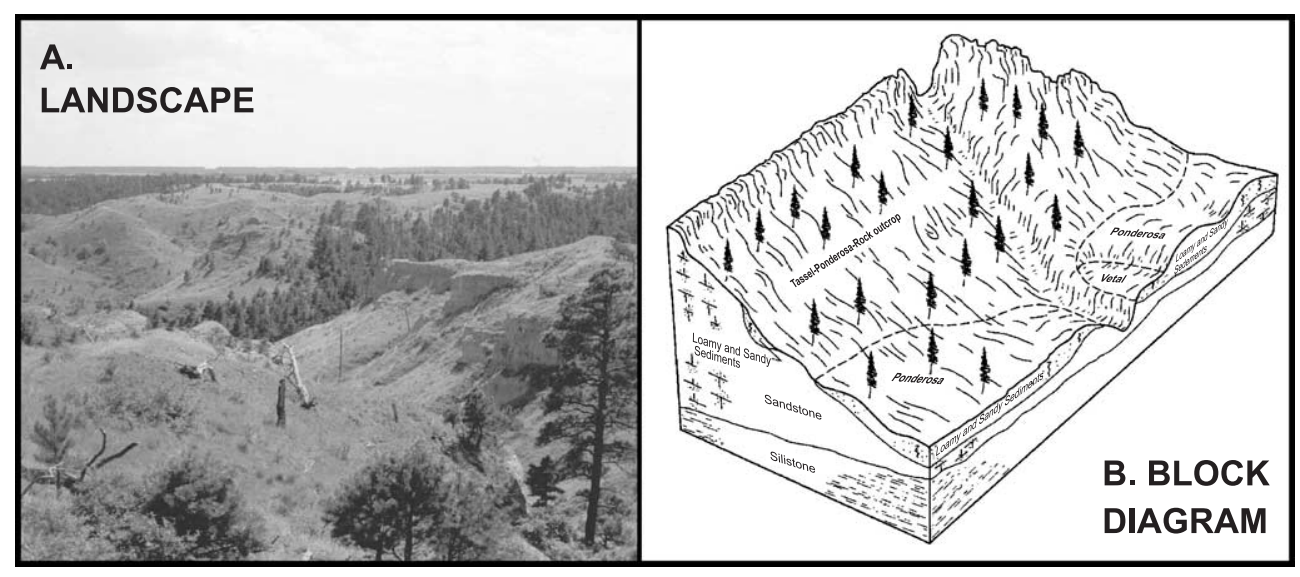

Fig. 2. Transfer of primary soil and landscape observations and information (e.g., A) actual landscapes) to stylized or idealized graphic (e.g., B) block diagram). 
Use of GIS and DEM technology now allows generation of geo-referenced block diagrams of actual landscapes rather than just stylized depiction. With this powerful capability goes a scientific responsibility. It is critically important that our understanding and portrayal of soil and lithostratigraphic relationships (e.g., superposition, inset, and on-lapping relationships, geomorphic setting, depth, and sequence relationships) be correct. If such relationships are vaguely understood or poorly portrayed, the results project weak scientific content. For example, in Fig. 3, note that Kyle soils occur both on ridge summits and on the stream terrace. The ridge summit is underlain by shale, but has received eolian inputs (Ragon et al., 1977). The terrace is underlain by alluvial substrata. This block diagram presents conflicting soil-to-substrata information. The same soil occurs on two different landscape positions and two different parent materials. The rationale for delineating one soil over two different parent materials is not stated (Ragon et al., 1977). Soil survey correlation can combine soils (map units) that have similar pedon characteristics and use and management. Soil map units separated during field activities are combined during correlation and given the same name. Although expedient for near-surface soil interpretations and succinct map legends, this "lumping" is confounding and "informationally" costly, especially in regard to the substrata information.
The Kyle map unit on the terrace will have contrasting alluvial sediment at depth, different subsurface water flow paths, and a field-recognizable landform. The geomorphic setting and substrata relationships argue for a distinct soil or at minimum a separate soil map unit for the terrace vs. adjacent hillslopes.

Soil map units may bear the same series name, but have a distinct slope class, substratum, or physiographic phase (Soil Survey Staff, 1993) to distinguish soils formed over different substrata, stratigraphic units, or geomorphic positions. Soil map unit definitions, mapping protocols, and map unit correlation must consider substrata and stratigraphic relationships, as well as upper horizon properties and soil interpretation.

Further, soil surveys should be correlative with other earth science data (surficial geology maps). Earth scientists, who want and need explicit lithostratigraphic or subsurface information, may otherwise disregard the soil map. In practice, the tandem use of soil and surficial geology maps obtains the most accurate information. Soil maps and the soil survey process should adhere to general earth science principles beyond pedology.

\subsection{Lithostratigraphy}

Lithostratigraphy is the discipline of geology that deals with the description (composition, texture,

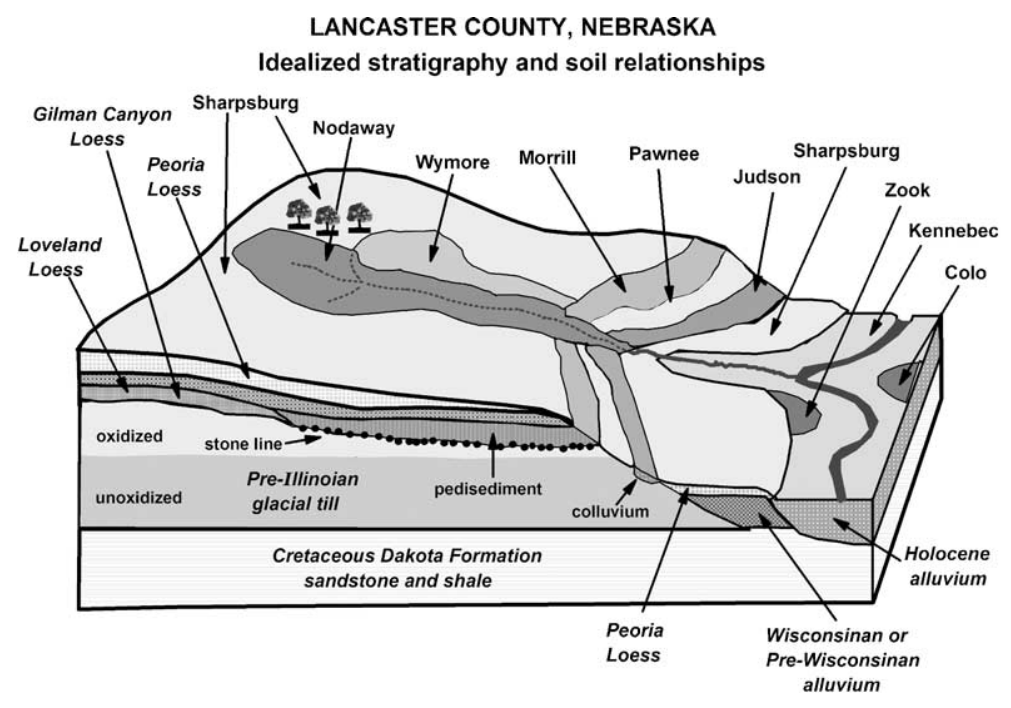

Fig. 4. Revised block diagram for Lancaster County, NE, USA that includes lithostratigraphic details to subsurface materials and links them to soil units and geomorphic setting. 
fabric, structure, and color) of strata, and their organization into recognized units based upon physical, chemical, and mineralogical characteristics. A lithostratigraphic unit is a mappable body of sedimentary (including unconsolidated sediments), extrusive igneous, metasedimentary, or a metavolcanic stratum that is distinguishable by field discernible characteristics and stratigraphic position (North American Commission on Stratigraphic Nomenclature, 1983). Formations (e.g., Entrada Sandstone) are the basic lithostratigraphic unit for mapping and interpreting regional geology. In like manner, soil map units are the basic unit for mapping and interpreting soils (Soil Survey Staff, 1993). Surficial lithostratigraphic units and soil maps units rarely, have one-toone correspondence. More commonly, a suite of soil map units will correspond to one or more lithostratigraphic units of similar lithic character.

Block diagrams can display important lithostratigaphic details including composition and age relationships without becoming overly specific or elaborate (Fig. 4). If known, block diagrams can and should identify formally named lithostratigraphic units. Field observations in road cuts, borings, and quarries; and well $\log$ data can yield relatively accurate depth relationships that can be used to construct block diagrams with precise vertical relationships. Soil map units that have correspondence to lithostratigraphic units provide a clear, linkage to subsurface materials.

Soil survey objectives and activities alone do not fully document the three-dimensional geometry of sediment and rock bodies, in particular depth. Soil scientists however, make numerous field observations that can confirm or refine surficial geology maps. They must understand sediment or rock body distribution to predict soil and landform patterns. In the soil survey process, soil scientists observe and map the surficial exposure of litho units. Studying and recording the transitional characteristics between soil and underlying lithostratigraphic units is an additional step, but a vital scientific contribution. Pedon descriptions can be easily modified to concisely display the relationships between soil horizons and stratagraphic units (Fig. 5). This relatively simple approach improves information communication, but also help focus soil surveyors on valuable strata relationships that might otherwise go unrecognized or undocumented.
STRATIGRAPHY

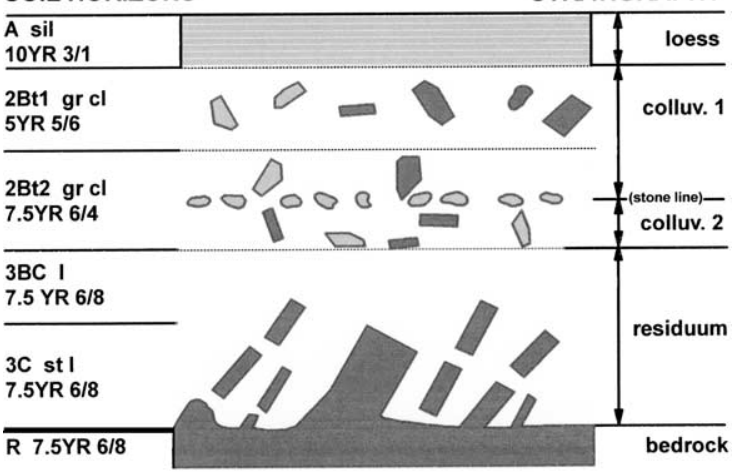

Fig. 5. Combined pedon and substrata description for presenting both pedostratigraphic and lithostratigraphic detail.

In a soil survey, several soil map units or a map unit suite (e.g., different slope phases or erosion classes) are generally mapped over a specific lithostratigraphic unit, and perhaps, closely related units. As mentioned earlier, users must glean the information from the map unit descriptions. A soil series or soil map unit to parent material array is a succinct means to convey information to users. Table 2 gives an example array developed for an existing soil survey (Brown et al., 1980) of Lancaster County, NE, USA Soil scientists often informally generate similar products to understand and learn the soil landscape relationships in a geographic area. Despite the succinct utility of a soil to parent material array, they rarely occur in soil survey publication.

\subsection{Pedostratigraphy}

Soil development produces horizons superposed onto landforms and parent materials. Episodic erosion and deposition (eolian and fluvial) can remove, truncate, and/or bury soil horizons. Spatial and/or temporal landscape stability permits initial and subsequent soil development. Thus, most landscapes are a mosaic of various-aged landforms, parent materials, soils, erosion events, and geomorphic surfaces. Surficial soils, buried soils, and paleosols, therefore, are a unique portion of the geomorphic and stratigraphic record in a region.

We define pedostratigraphy here as the study of the stratigraphic relationships and implications of soils (including buried soils) and paleosols. Soil horizons are morphologically distinct, laterally traceable, and a 
Table 2

Soil and parent material array for Lancaster County, NE soil survey (Brown et al., 1980)

\begin{tabular}{|c|c|c|c|c|c|}
\hline \multirow[t]{2}{*}{ Parent material } & \multicolumn{5}{|c|}{ Soil series name and classification } \\
\hline & EXD & WD & MWD & SWPD & PD \\
\hline Alluvium & & $\begin{array}{l}\text { Dickinson } \\
\text { Typic Hapludoll }\end{array}$ & $\begin{array}{l}\text { Kennebec } \\
\text { Cumulic Hapludoll } \\
\text { Nodaway } \\
\text { Mollic Udifluvent }\end{array}$ & $\begin{array}{l}\text { Colo } \\
\text { Cumulic Haplaquoll } \\
\text { Lamo } \\
\text { Cumulic Haplaquoll }\end{array}$ & $\begin{array}{l}\text { Fillmore } \\
\text { Typic Argialboll } \\
\text { Salmo } \\
\text { Cumulic Haplaquoll } \\
\text { Wabash } \\
\text { Vertic Haplaquoll } \\
\text { Zook } \\
\text { Cumulic Haplaquoll } \\
\text { Zoe } \\
\text { Cumulic Haplaquoll }\end{array}$ \\
\hline Colluvium & & & $\begin{array}{l}\text { Judson } \\
\text { Cumulic Hapludoll }\end{array}$ & & \\
\hline Lacustrine Sediments & & $\begin{array}{l}\text { Malcolm } \\
\text { Typic Argiudoll }\end{array}$ & & & \\
\hline Peoria Loess & & & $\begin{array}{l}\text { Crete } \\
\text { Pachic Argiustoll } \\
\text { Sharpsburg } \\
\text { Typic Argiudoll }\end{array}$ & $\begin{array}{l}\text { Butler } \\
\text { Abruptic Argiaquoll } \\
\text { Wymore } \\
\text { Aquic Argiudoll }\end{array}$ & \\
\hline Loveland Loess & & $\begin{array}{l}\text { Morril } \\
\text { Typic Argiudoll }\end{array}$ & & & \\
\hline Erosion Lag & & $\begin{array}{l}\text { Geary } \\
\text { Udic Argiustoll }\end{array}$ & $\begin{array}{l}\text { Mayberry } \\
\text { Aquic Argiudoll }\end{array}$ & & \\
\hline Residuum & $\begin{array}{l}\text { Hedville } \\
\text { Sandstone Lithic Haplustoll } \\
\text { Sogn } \\
\text { Limestone Lithic Haplustoll }\end{array}$ & & & & \\
\hline Till & $\begin{array}{l}\text { Steinauer } \\
\text { Typic Udorthent }\end{array}$ & $\begin{array}{l}\text { Burchard } \\
\text { Typic Argiudoll }\end{array}$ & $\begin{array}{l}\text { Pawnee } \\
\text { Aquic Argiudoll } \\
\text { Shelby } \\
\text { Typic Argiudoll }\end{array}$ & & \\
\hline
\end{tabular}

$\mathrm{EXD}=$ excessively drained, $\mathrm{WD}=$ well drained, $\mathrm{MWD}=$ moderately well drained, $\mathrm{SWPD}=$ somewhat poorly drained, $\mathrm{PD}=$ poorly drained.

time marker. Soil possesses stratigraphic importance. Soil horizons can be contained within or cross cut substrata and landforms. The soil stratigraphic relationships are important for determining the geomorphic history of an area.

Soils or paleosols need not be formally defined stratigraphic units to possess geomorphic, stratigraphic, and interpretive value. Formal stratigraphic recognition is possible. For example the North American Commission on Stratigraphic Nomenclature (1983) recognizes and defines a pedostratigraphic unit as a rock body consisting of one or more pedologic horizons that is laterally traceable, mappable, and has consistent stratigraphic position and that is overlain by one or more lithostratigraphic units. The term rock here refers to both consolidated and unconsolidated materials.
In a sense, it is incongruous that soil surveys present spatial soil patterns, but do not wholly convey or portray horizon continuity and stratigraphy. Soil surveys provide detailed horizon sequence and properties via pedon descriptions (Table 1). Soil horizon continuity and character, including buried soils or paleosols, across and within landscape and/or parent materials are valuable interpretive information, which receive little discussion or presentation in soil surveys. Soil surveys should link soil distribution, pedostratigraphy, lithostratigraphy, and landscape hydrology.

Two-dimensional graphics (Fig. 6) are an uncomplicated approach to highlight and display essential pedostratigraphic features and water table relationships found in an inventory area. Simple, well-done graphics communicate a complex set of spatial patterns and stratigraphic information in a succinct form. As shown 


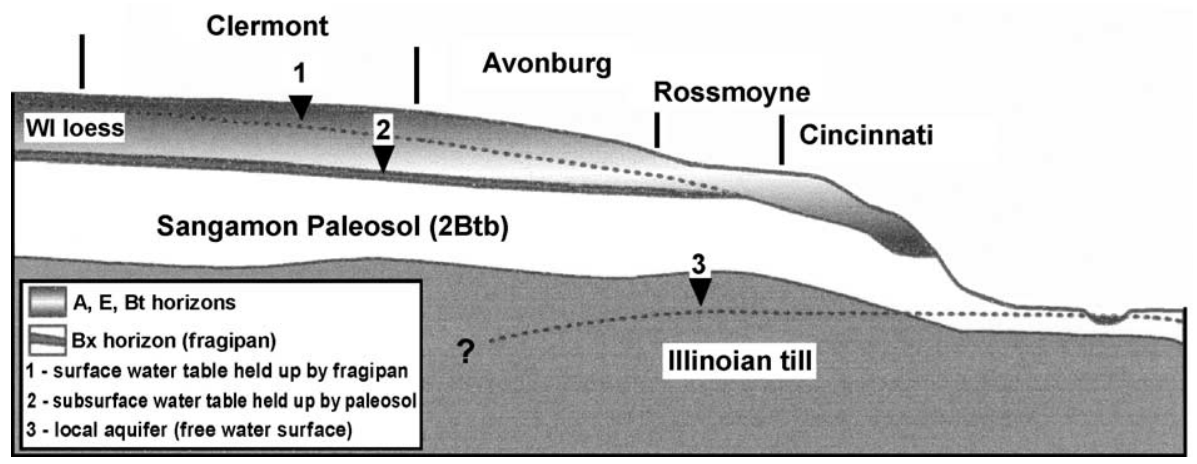

Fig. 6. Soil landscape pattern, pedostratigraphy, lithostratigraphy, and water tables on the Illinoian till plain of southern Indiana, USA (modified from Jenkinson and Franzmeier, 1996).

in Fig. 6, pedostratigraphy directly affects soil patterns and water movement on landscapes.

Pedogenic processes modify geologic material by removing material (e.g., weathering and leaching minerals), adding material (e.g., organic materials), redistributing (e.g., clay illuviation), or transforming material (e.g., in situ clay formation) (Simonson, 1959). These processes thereby affect the way and extent to which water moves through the resultant soil landscape. For example, fragipans, argillic horizons, and pore size discontinuities (O'Geen et al., 2003; Kemp et al., 1998; McDaniel and Falen, 1994; Driese et al., 2001) can profoundly affect water flow direction and timing on a soil landscape. Moreover, multiple paleosols or buried soils occur predominantly in two main geomorphic settings - alluvial sequences (flood plain and terrace systems and alluvial fans) and geologic deposits formed from multiple eolian additions (eolian sands, loess, and volcanic ash). The pedostratigraphy in these landscapes is a field record of the geomorphic history and can have archeological significance (Bettis, 1992).

Soil surveys can fulfill a unique role in gathering and displaying pedostratigraphic information because of its general absence in geologic information. Geologic sections rarely show pedostratigraphic features and attributes (e.g., soil horizons or paleosols). Additionally, soils and paleosols of different ages are generally not distinguished (partially a function of map scale). Although buried soils or paleosols may not be mappable in a soil survey, their presence can be denoted in pedon and map unit descriptions (e.g., A, Bt, $\mathrm{BC}, 2 \mathrm{Btb}, 2 \mathrm{CB})$ and in graphics.

\subsection{Measured sections}

Soil surveys convey horizon and depth information via a typical pedon description, which includes the exact location. This convention arises from a historic linkage with geology and is similar to the practice of designating formational stratotypes. Measured sections that incorporate pedon and parent material properties, pedostratigraphy, and lithostratigraphic description provide robust and durable documentation. Fig. 7 is a graphic example of a measured alluvial section in northwest Nebraska. The graphic includes both pedologic and geologic description and information. The description extends through the entire alluvial sequence and gives both surface soil and substrata information. Measured sections of important exposures are permanent records of interest to land management and earth science users. Over the approximate 25-year life span of a typical soil survey, earth scientists will revisit stratotypes to gather additional information for applications and subjects (e.g., geology, archeology, education, and paleoclimatology) beyond the scope of typical soil surveys.

The process of documenting and presenting measured sections in soil survey improves field descriptive skills and encourages closer subsolum scrutiny. Soil scientists have the basic skills and training to make these observations and to present the resulting information. Soil scientists, using inexpensive tools (e.g., hand level, clinometer or Abney Level and a stadia rod or folding carpenter's rule) and established techniques (Compton, 1985; Maley, 1994), can document sections at road cuts or other exposures, or via drill cores 


\section{ARNER PIT HEARTH SITE MEASURED SECTION \#30}
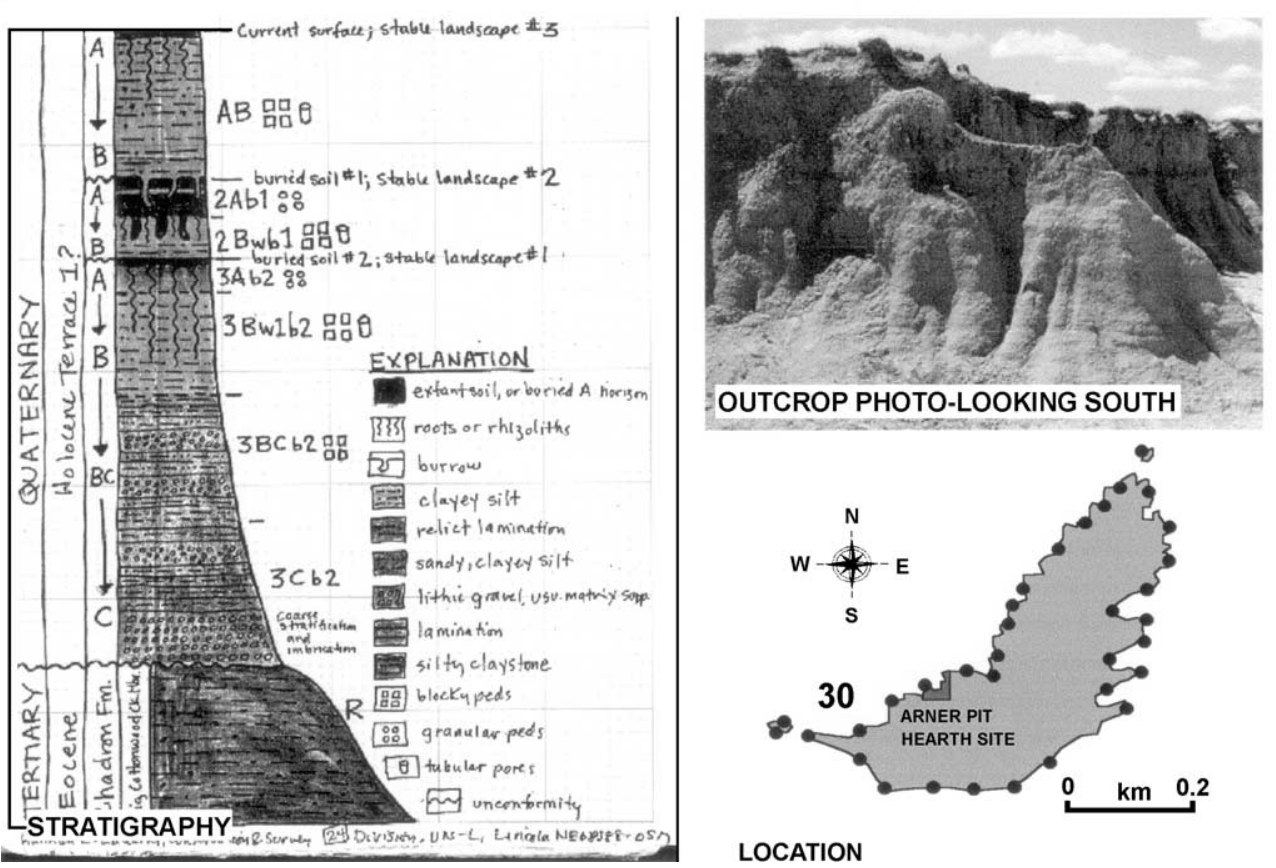

Fig. 7. Measured alluvial section with pedostratigraphic detail Arner Pit Hearth Site northwest Nebraska (LaGarry, 2000).

(Fig. 8). More sophisticated methods and equipment can be used to good effect, but are not required.

\subsection{Parent material maps}

As discussed previously, soil survey users must reconstruct or interpret substrata information from pedon and map unit descriptions. This task is tedious and subject to error. Soil surveys could include more direct parent material information, which is linked to soil properties and patterns. Soil surveys invariably include a general soil map for the inventory area. The basis for a general soil map relies heavily on three attributes - regional parent material distribution, soil landform relationships, and vegetation type. A general soil map by itself does not convey the soil to parent

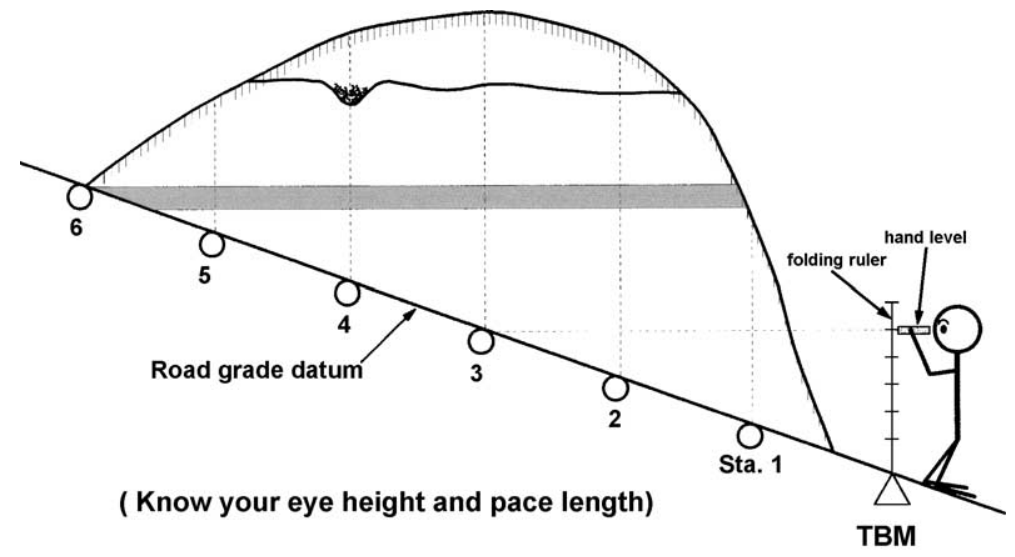

Fig. 8. Basic tools and principles for measured sections. 


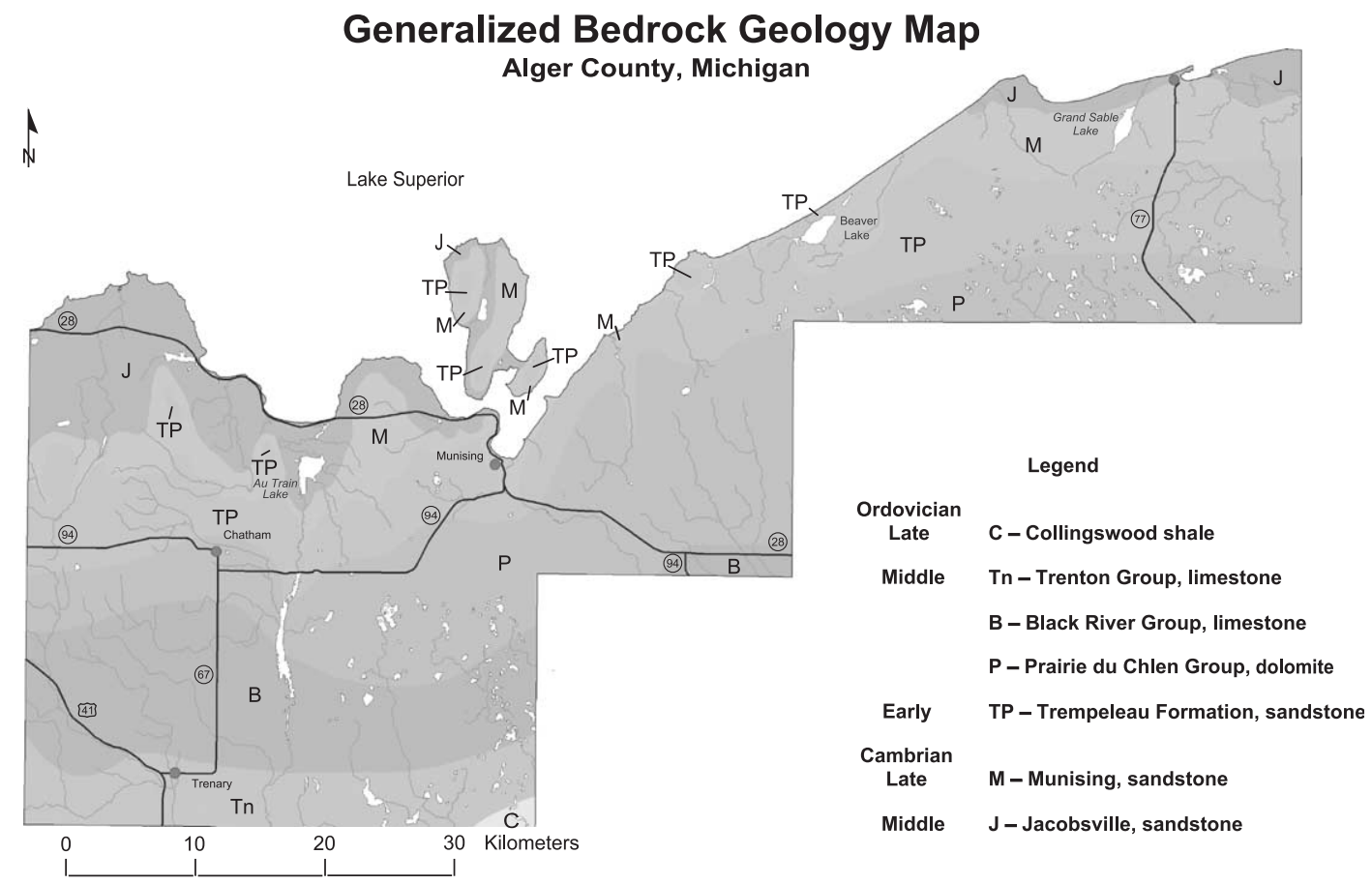

Fig. 9. Bedrock map Alger County, Michigan, USA (Schwenner, 2000).

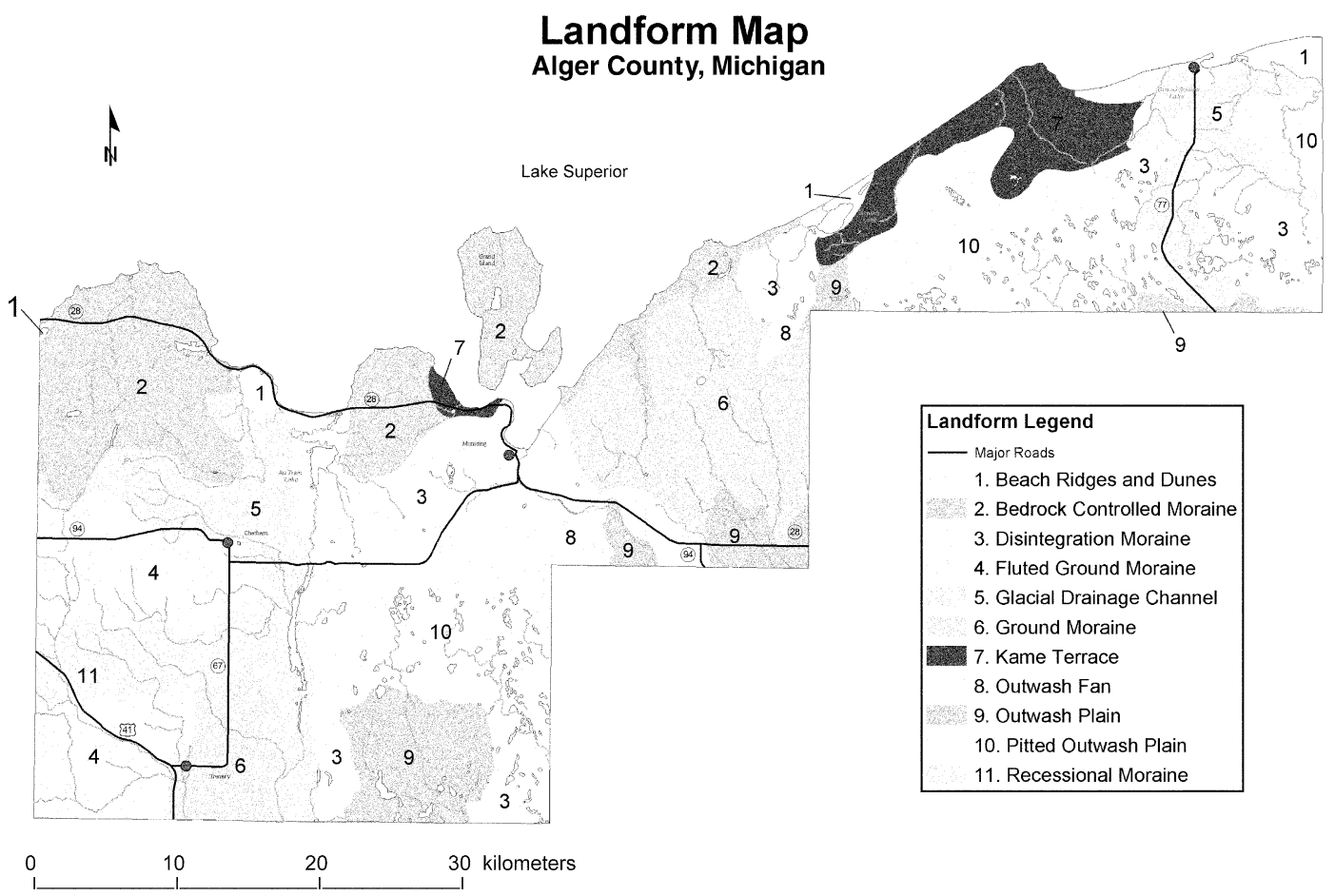

Fig. 10. Landform map Alger County, Michigan, USA (Schwenner, 2000). 
material or soil to landform relationships. Separate maps on scales similar to the general soil map can display parent material (e.g., sediments, saprolite, or bedrock) distribution. An example of bedrock distribution for Alger County, MI (Schwenner, 2000) is shown in Fig. 9.

Soil scientists often generate working copies of parent material distribution from existing information. This serves two purposes. The first we mentioned-to understand general soil distribution. The second purpose is as a field predictor during the soil mapping process. As soil mapping progresses and field observations confirm or refute the known or expected parent material distribution. Soil scientists modify parent material maps, as necessary.

\subsection{Geomorphic maps}

Geomorphic maps visually convey landform, soil, and parent material information (Fig. 10). A geomorphic map provides a landscape context for understanding and predicting soil occurrence. Along with parent material distribution, soil scientists commonly generate working copies of landform or geomorphic maps. Soil survey publications, particularly given the Major Land Resource Area approach, should include geomorphic maps. Geomorphic maps are succinct means to convey landform distribution and soil landform relationships identified during the soil survey. Formalizing and including landform maps in soil surveys would help quantify and convey soil landscape relationships in a soil inventory region.

\section{Conclusions}

A wealth of subsolum information, including characteristics of the soil-to-substrata transition, is observed during and can be documented in soil surveys. Soil scientists can enhance parent material and substrata information in soil surveys, and attract a wider audience for soil survey products, by: 1) presenting existing subsolum information in published soil surveys in a comprehensive, precise format. 2) Documenting and retaining subsolum information currently lost during the soil survey process and 3) including complementary subsurface information to augment traditional soil survey data. We suggest the following approaches and concepts to capture and convey parent material and subsolum information in soil surveys.

1) Block diagrams

2) Lithostratigraphy

3) Pedostratigraphy

4) Parent material maps and tables

5) Geomorphic maps

Soils and soil surveys are a window to the subsurface. It is incumbent on us as soil scientists to integrate our understanding with other earth sciences and better serve soil survey users. Soil surveys should transmit a clear image and understanding of both the solum and subsolum. Detailed observations of soil properties when linked to subsolum information (e.g., drill cores and geologic sections) and other earth science inventories can provide a coordinated, comprehensive earth material inventory.

\section{References}

Bettis III, E.A., 1992. Soil morphologic properties and weathering zone characteristics. In: Holiday, V.T. (Ed.), Soils in archeology. Smithsonian Institution Press, Washington D.C., pp. 119-144.

Brown, L.E., Quandt, L., Scheinost, S., Wilson, J., Witte, D., Hartung, S., 1980. Soil survey of lancaster county Nebraska. USDA, Soil Conservation Service. U.S. Gov. Print. Office, Washington, DC.

Buol, S.W., 1994. Saprolite-regolith taxonomy-an approximation. In: Creemans, D.L., Brown, R.B., Huddleston, J.H. (Eds.), Whole regolith pedology. SSSA Special Publication, vol. 34. Soil Science Society of America, Madison, WI, pp. 119-132.

Chadwick, O.A., Graham, R.C., 2000. Pedogenic processes. In: Sumner, M. (Ed.), CRC handbook of soil science. CRC Press, New York, pp. E41-E73.

Clayton, J.L., Arnold, J.F. 1972. Practical grain size, fracturing density, and weathering classification of intrusive rocks of the Idaho batholith. USDA, Forest Service, General Tech. Report INT-2, Intermoutain Forest and Range Exp. Sta. USDA-FS Ogden, Utah.

Compton, R.R., 1985. Geology in the Field. John Wiley \& Sons, New York, NY.

Driese, S.G., McKay, L.D., Penfield, C.P., 2001. Lithologic and pedogenic influences on porosity distribution and groundwater flow in fractured sedimentary saprolite: a new application of environmental sedimentology. J. Sediment. Res. 71, 843-857.

Frazier, C.S., Graham, R.C., 2000. Pedogenic transformation of fractured granitic bedrock, southern California. Soil Sci. Soc. Am. J. 64, 2057-2069. 
Frazier, C.S., Graham, R.C., Shouse, P.J., Yates, M.V., Anderson, M.A., 2002. A field study of water flow and virus transport in weathered granitic bedrock. Vadose Zone J. 1, 113-124.

Follmer, L.R., 1979. Explanation of pedologic terms and concepts used in the discussion of soils for this guidebook. Appendix3. Wisconsinan, Sangamonian, and Illinoian Stratigraphy in Central Illinois: Midwest Friends of the Pleistocene 26th Field Conf., Campaign, IL, Illinois Geol. Surv., Guidebook, vol. 13, pp. 129-134.

Graham, R.C., and Wald, J., 1999. Preliminary report: hydrologic and ecosystem functions of paralithic materials: Assessment of the soil-lithosphere interface. USDA NRCS Award No. 68-7482-7-313). Soil and Water Science Program. Dept. Environmental Sciences, University of California, Riverside, CA.

Graham, R.C., Guertal, W.R., Tice, K.R., 1994. The pedologic nature of weathered rock. In: Creemans, D.L., Brown, R.B., Huddleston, J.H. (Eds.), Whole regolith pedology. SSSA Special Publication, vol. 34. Soil Science Society of America, Madison, WI, pp. 12-40.

Hallberg, G.R., Fenton, T.E., Miller, G.H., 1978. Standard weathering zone terminology for the description of Quaternary sediments in Iowa. Part 5. In: Hallberg, G.R. (Ed.), Standard procedures for evaluation of Quaternary materials in Iowa. Iowa Geol. Surv. Tech. Info. Serial, vol. 8, pp. $75-109$.

Jenkinson, B.J., and Franzmeier, D.P., 1996. Soil moisture regimes of some topsequences in Indidana. In: Wakeley, J.S., Sprecher, S.W., Lynn, W.C. (eds.), Preliminary investigations of hydric soil hydrology and morphology in the United States. Wetlands Research Progam Technical Report WRP-DE-13. US Army Corps of Engineers, Waterway Experiment Station. Vicksburg, MS.

Kemp, R.A., McDaniel, P.A., Busacca, A.J., 1998. Genesis and relationship of macromorphology and micromorphology to contemporary hydrological conditions of a welded Argixeroll from the Palouse in NW USA. Geoderma 83, 309-329.

LaGarry, H.E., 2000. Personal Communication.

Langton, J.E., Simonson, D.T., 2001. Soil survey of Jackson County Wisconsin. USDA, Natural Resource Conservation Service, U.S. Gov. Print. Office, Washington, DC.

Maley, T.S., 1994. Field Geology Illustrated. Mineral Land Publications, Boise, ID.

McDaniel, P.A., Falen, A.L., 1994. Temporal and spatial patterns of episaturation in a Fragixeralf landscape. Soil Sci. Soc. Am. J. $58,1451-1457$.

McCoy, G.L., Rayer, R.L., Mahnke, C.F., Shurtliff, D.R., Voigtlander, AL., Latta, C.W., Young, P.D., Hoover, D.R., Babcock, M.K. Green, J.A., Worm, J.F., Lobaugh, S.J., Stolpe, N.B., Morris, C.E., 2002. Soil survey Sheridan County Nebraska. USDA, Natural Resource Conservation Service. U.S. Gov. Print. Office, Washington, DC.

Moody, L.E., Graham, R.C., 1994. Pedogenic processes in thick sand deposits on a marine terrace. In: Creemans, D.L., Brown, R.B., Huddleston, J.H. (Eds.), Whole regolith pedology. SSSA Special Publication, vol. 34. Soil Science Society of America, Madison, WI, pp. 41-56.
North American Commission on Stratirgraphic Nomenclature, 1983. North American Stratigraphic Code. Am. Assoc. Pet. Geol. Bull. 67, 841-875.

O'Geen, A.T., McDaniel, P.A., Boll, J., Brooks, E., 2003. Hydrologic processes in valley soilscapes of the eastern Palouse basin in northern Idaho. Soil Sci. 168 (12), 846-855.

Otter, A.J., Fiala, W.D. 1978. Soil Survey of Portage County Wisconsin. USDA, Soil Conservation Service. U.S. Gov. Print. Office, Washington, DC.

Pavich, M.J., Leo, G.W., Obermeier, S.F., Estabrook, J.R., 1989. Investigations of the characteristics, origin, and residence time of the upland residual mantle of the Piedmont of Fairfax County, Virginia. USGS Professional Paper, vol. 1352. US Gov. Printing Office, Washington, DC.

Prescott, J.A., Pendlton, R.L., 1952. Laterite and lateritic soils. Commonw. Bur. Soil Sci., Tech. Commun., 47.

Ragon,L.G., Worth, L.D., Sherwood, M.A., Fausch, L., 1977. Soil survey of Dawes County Nebraska. USDA, Soil Conservation Service. U.S. Gov. Print. Office, Washington, DC.

Richardson, J.L., Lietzke, D.A., 1983. Weathering profiles in fluvial sediments of the Middle Coastal Plain of Virginia. Soil Sci. Soc. Am. J. 47, 301-304.

Richardson, J.L., Arndt, J.L., Montgomery, J.A., 2001. Hydrology of wetland and related soils. In: Richardson, J.L., Vepraskas, M.J. (Eds.), Wetland soils—genesis, hydrology, landscapes, and classification. Lewis Publishers, New York, NY, pp. 35-84.

Schoeneberger, P.J., Amoozegar, A., 1990. Directional saturated hydraulic conductivity and macropore morphology of a soilsaprolite sequence. Geoderma 46, 31-49.

Schoeneberger, P.J., Amoozegar, A., Buol, S.W., 1995. Physical property variation of a soil and saprolite continuum at three geomorphic positions. Soil Sci. Soc. Am. J. 59, 1389-1397.

Schoeneberger, P.J., Wysocki, D.A., Benham, E.C., Broderson, W.D., 2002. Field book for describing and sampling soils (version 2.0). USDA-Natural Resource Conservation Service, Lincoln, NE.

Schwenner, C., 2000. Personal communication.

Simonson, R.W., 1959. Outline of a generalized theory of soil genesis. Proc. - Soil Sci. Soc. Am. 23, 153-156.

Smith, G.D., 1986. The Guy Smith interviews: rationale for concepts in soil taxonomy. Soil management Support Services Technical Monograph, vol. 11. Cornell Univ, Ithaca, NY.

Soil Science Society of America, 1997. Glossary of soil science terms. Soil Science Society of America, Madison, WI.

Soil Survey Staff, 1975. Soil taxonomy. USDA-NRCS, US Government Printing Office, Washington, DC.

Soil Survey Staff, 1993. Soil survey manual. USDA Handbook, vol. 18. U.S. Government Printing Office, Washington, DC.

Soil Survey Staff, 1998. Keys to soil taxonomy, 8th ed. US Government Printing Office, Washington, DC.

Soil Survey Staff, 1999. Soil Taxonomy, 2nd ed. USDA-NRCS, US Government Printing Office, Washington, DC.

Stolt, M.H., Baker, J.C., 1994. Strategies for studying saprolite and saprolite genesis. In: Creemans, D.L., Brown, R.B., Huddleston, J.H. (Eds.), Whole regolith pedology. SSSA Special Publication, vol. 34. Soil Science Society of America, Madison, WI, pp. 1-19. 
Stone, E.L., Commerford, N.B., 1994. Plant and animal activity below the solum. In: Creemans, D.L., Brown, R.B., Huddleston, J.H. (Eds.), Whole regolith pedology. SSSA Special Publication, vol. 34. Soil Science Society of America, Madison, WI, pp. 57-74.

Tandarich, J.P., Follmer, L.R., Darmody, R.G., 1994. The pedoweathering profile: a paradigm for whole-regolith pedology from the glaciated midcontinental United States of America. In: Creemans, D.L., Brown, R.B., Huddleston, J.H. (Eds.), Whole regolith pedology. SSSA Special Publication, vol. 34. Soil Science Society of America, Madison, WI, pp. 97-118. van Dijk, D.C., 1969. Pseudogley in Gundaroo subsola, Southern Tableland, New South Wales. Aust. J. Soil Res. 7, 143-162.

Vepraskas, M.J., Jongmans, A.G., Hoover, M.T., Bouma, J., 1991. Hydraulic conductivity of saprolite as determined by channels and porous groundmass. Soil Sci. Soc. Am. J. 55, 932-938.

Wysocki, D.A., Schoeneberger, P.J., LaGarry, H.E., 2000. Geomorphology of soil landscapes. In: Sumner, M. (Ed.), CRC handbook of soil science. CRC Press, New York, pp. E1-E39. 